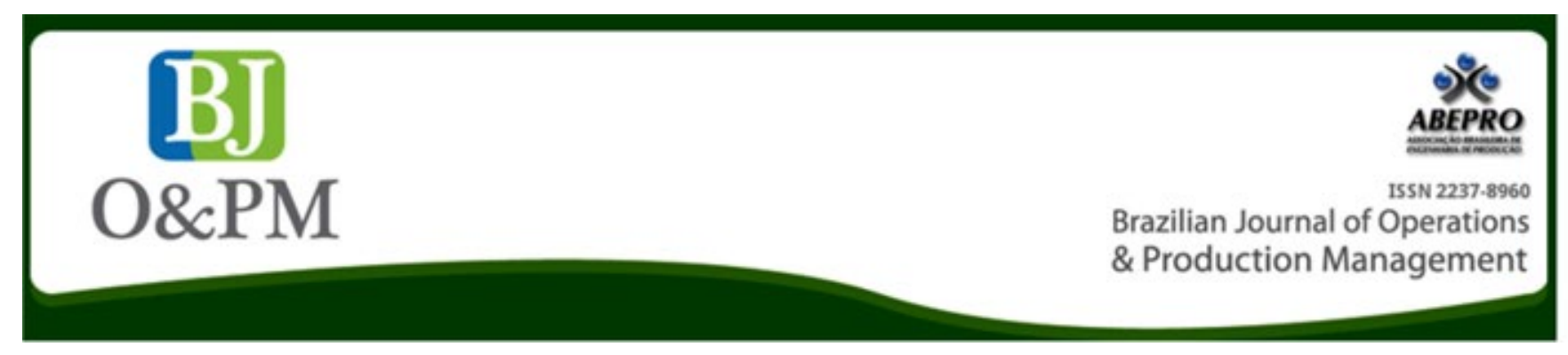

\title{
WORKER-RECOVERED COMPANIES IN BRAZIL: SELF-MANAGEMENT PROCESS ASSESSMENT BY APPLYING MULTI-CRITERIA DECISION SUPPORT TOOLS
}

\author{
Fernanda Araujo ${ }^{1}$, Vicente Nepomuceno ${ }^{2}$, Helder Costa ${ }^{3}$, Denise Alvarez ${ }^{3}$ \\ 1 Celso Suckow da Fonseca Federal Center for Technological Education - RJ \\ 2 Federal University of Rio de Janeiro State \\ 3 Fluminense Federal University
}

\begin{abstract}
Company recovery is a practice developed by workers who, in the imminence of becoming unemployed, negotiate or fight for access to the means of production of bankrupting companies, and start to manage them collectively, guided by the principles of self-management. Nevertheless, how to assess self-management in worker-recovered companies (WRCs)? The criteria selected by a bibliographic review on the concept of self-management were used in dealing with the data collected by the Brazilian WRCs national mapping. A multi-criteria decision support tool was used to build a model for analyzing and classifying the companies in three categories related to their form of management. The multi-criteria approach allowed to create an assessment of self-management practices in the WRCs studied.
\end{abstract}

Keywords: Worker Recovered Companies (WRCs); Self-Management; Multi-Criteria Approach. 
Brazilian Journal of Operations \& Production Management

Volume 14, Número 1, 2017, pp. 249-264

DOI: 10.14488/BJOPM.2017.v14.n2.a13

\section{INTRODUCTION}

In the last 100 years, workers have taken up factories and other work and production spaces, creating worker councils or self-managing companies in several regions of the planet. In the book "Ours to Master and to Own: Workers' Control from the Commune to the Present" (2011), Immanuel Ness and Dario Azzelini gather reports on worker management experiences in Russia, Germany, Italy, Spain, USA, England, Indonesia, Poland, Portugal, India, Algeria, Canada, Argentina, Brazil, and Venezuela. The common feature of these experiences is the workers' fight for more participation in the management of the companies. The authors recognize in this movement an emancipating character of the workers' fight, which aims at transforming a situation into alienation of/in work by building workspaces, which are more democratic and assure the subjects more autonomy.

In Latin America, the experiences in worker self-management are manifested, among other forms, significantly in processes of company recovery by workers. Company recovery is a practice developed by workers who, in the imminence of becoming unemployed, negotiate or fight for access to the means of production of bankrupting companies, and start to manage them collectively guided by the principles of self-management. Ruggeri (2009) defines company recovery as a social and economic process that assumes the existence of a previous capitalist company whose bankruptcy or economical unviability has resulted in the worker's fight to protect them.

Bankrupt companies recovery by their workers has stood out in the international media, as pointed out by Jensen (2011). Despite this, the totality of these experiences in Brazil was unknown. The national mapping of worker-recovered companies (WRCs) in Brazil, performed in 2011 and 2012, identified the existence of 67 companies with these characteristics in the country. That research gathered a set of information about those companies, which are systematized in a database. That material allows for a series of analyses on the phenomenon.

One of the possibilities of analysis envisioned from the organization of that database is on what concerns dealing with the information generated about the forms and mechanisms of management put into practice by those experiences. Above, it was pointed out that the essential difference of the WRCs in relation with the bankrupt company that originated them is in the form of collective management by the workers, guided by the principles of self-management. Thus, the following questions arised: how has this guidance been put into practice by the WRCs? How to assess the self-management processes in course in the companies?

In order to answer the central questions, we formulated some auxiliary questions that guide this study. Which are:
- Which criteria can be adopted to assess the self-management processes in course in the Worker Recovered Company?

- How can these criteria be used to deal with the information registered in the database built by the national mapping of Brazilian WRCs?

- How to assess and classify the WRCs researched based on the criteria defined?

This research objective is to build a model guided by the multi-criteria approach, which allows generating an assessment and classification of the Brazilian WRCs according to their forms of management. This general objective may be dissected in the following specific objectives:

- Define criteria for assessing the self-management processes in the WRCs;

- Design a model that considers these criteria for dealing with the data produced by the national mapping of the companies;

- Evaluate and classify the companies researched, according to their proximity to an ideal of self-management.

In order to reach the objectives proposed, the work starts with a bibliographic review on the WRCs theme in Brazil, Latin America and the world, and on the concept of self-management. The review had the purpose of identifying criteria that might be adopted to assess the self-management processes in course in the WRCs.

The next step was to specify the scales for judging the criteria: "questions" asked by the time of the national mapping of the WRCs that was related to the criteria defined were selected, and weights were globally assigned to the criteria and each particular "question". Then forms of analysis were elaborated for each question and each WRC was assessed according to the form of judgment defined.

Next, the De Borda method was performed for classifying the companies according to their form of management. Finally, the analysis results were submitted to evaluation to a group of experts in the theme, intending to check their reliability.

\section{WRCS IN BRAZIL, LATIN AMERICA AND THE WORLD}

In the article entitled "Cooperatives, Worker-Owned Enterprises, Productivity and the International Labor Organiza- 
tions", Logue et Yates (2006) present a multinational review where the International Labor Organization (ILO) acknowledges the importance of cooperatives and worker-managed companies to rebuilding the forms of work in several countries, especially in context of crisis. A conclusion of the study is that productivity in these companies increases if the collective ownership comes with forms of participative management. The authors also concluded that in different countries these companies have contributed to creating jobs and a more dignified life for the workers. At last, Logue et Yates (2006) pointed out that these companies contribute to the surrounding communities' life by teaching participation techniques and self-government, and they can be the basis for a development strategy from the creation of networks between cooperatives.

Jensen (2011) shows that company recovery was an important strategy in creating jobs during the crisis time in Spain in the early ' 80 s. Recently an European Meeting of Worker-Recovered Companies took place in Marseille, in France, gathering several experiences similar in countries such as Italy, France, Greece, and Spain (Karyotis, 2014).

The first cases of worker recovered companies (WRCs) identified in Latin America are in the Brazilian territory and date back to the 1980s. The strong crisis resulting from the advancement of neoliberal policies put into practice, especially from the 1990s, drove on the phenomenon. Data from SERASA (2010) show a vertiginous increase in terms of the number of bankruptcy requests in Brazil in that period. In the year 1996, there were 48,169 bankruptcy requests in the country, whereas in 1991 that number was only 12,847. In this scenario, company recovery became a solid life alternative for the workers before the increasing unemployment ${ }^{1}$.

However, this phenomenon was not restricted to the Brazilian territory. Data from the Economic Commission for Latin America and the Caribbean (CEPAL, 1997) show that at that time the urban areas of Argentina had a high unemployment rate growth, reaching $17.5 \%$ a year in 1995 , contrasting with figures in the range of $7.5 \%$ in the previous decade. With the worst crisis ever experienced in that country's history, started in 2001, the unemployment rate reached $19.7 \%$ in 2002. About 30 thousand enterprises shut down and 750 thousand job positions were lost (around $5 \%$ of wage earners).

The Argentinians react to the crisis by recovering compa-

1 Lima (2007) shows that the creation of self-management companies in Brazil in the context of globalization was not always the workers' initiative before the bankrupt companies. Some cases were created by the companies' own interest or even the State's interest, interested in reducing costs. Lima suggests caution when assessing experiences, as they may show the opposite of a construction of a work model to a new form of casualization. nies from several industrial and service sectors. Since 2005, a group of researchers from the University of Buenos Aires has been conducting national surveys in its country's WRCs. The surveys show that the number of companies with that feature has been growing year after year, making Argentina the Latin American country that concentrates the most remarkable and numerous experiences today. In the fourth survey report, published in 2013, 311 WRCs were identified, involving a total of 13,462 workers (Ruggeri, 2014).

Less intensely, the phenomenon of company recovery by workers is also seen in Uruguay, Peru, Paraguay, Venezuela, Mexico, and Colombia, where a few cases were identified. Researchers who dedicate themselves to this thematic in those different countries have been seeking to join efforts to make a Latin American mapping of the experiences.

In Brazil, a group of researchers involving 11 Brazilian universities got inspired in the Argentinian experience to make, between 2011 and 2012, the first national mapping of worker-recovered companies in the country. The research had a national coverage and identified the existence of 67 WRCs working and other 73 WRCs, which for several reasons did not work anymore.

Besides the general features of those organizations (such as location, number of workers involved and type of activity), the research sought to identify other aspects from the following axes: the recovery process; legal framework; workers' profile; production and technology; work relations; organizational profile; commercialization and credit; social work security; relationship with social movements and unions; relationship with the state and; self-assessment of the experience.

With a focus on the working WRCs, the group visited and interviewed representatives of 52 from the universe of 67 WRCs. The results of the interviews were systematized in a database and recently published in the book Empresas Recuperadas por Trabalhadores no Brasil (Companies Recovered by Workers in Brazil) (Henriques, et al. 2013). That material will be the main raw material for the analyses that are presented in the sequence of this article.

The use of a quantitative database to evaluate self-management must be done very carefully. The understanding in terms of the self-management phenomenon is full with contradictions and "paradoxes", and it is necessary to highlight those contradictions in order to understand those organizations (Westenholz, 1999). The research material used as a base for this article will not allow for a deeper qualitative analysis of each case and their contradictions. Even so, it is considered important to identify criteria that contribute to an assessment of self-management in a quantitative perspective, where the universe of the enterprises can be considered. 
Before moving on to the analyses, it is necessary to clarify the origin of the criteria that were adopted. As put previously, efforts were made to identify in this database that gathers information about the Brazilian WRCs, some elements that are about the forms and mechanisms of management put into practice through those experiences. From that information, we intend to evaluate how much self-management, as a principle declared by the WRCs, is present in the forms of management of those companies. For that, it is necessary to clarify what we understand as self-management.

\section{SELF-MANAGEMENT: THEORY AND PRACTICE}

The debate about the concept of self-management mobilizes and has mobilized several thinkers for many years. Many studies contribute to understanding the phenomena of company management by the workers (Jensen, 2011, Lima, 2007; Deutsch, 2005; Cornforth, 2004; Viggiani, 1997; Mygind, 1993).

Jensen (2011) proposes dividing those studies into 4 schools:

Skeptics - it adopts a negative position. They believe that it is not a viable model to aspire capitalism transformation. Its democratic model will degenerate and reproduce the deficiencies of capitalism.

1. Revisionists - it challenges the skeptics' theories by always facing new evidences.

2. They make a new review of skeptics from the appearance of cases of recovered companies in Europe. They showed that many companies survived and grew up democratically.

3. Contextualists - the existence of worker-managed companies reflects a historical, political, social and economic conjuncture. This school proposes to explain why these companies, which may have a performance superior to the conventional companies, prevail more in some countries than in others. According to this school, self-management will have radically different effects depending on the context in which it is inserted.

4. Evolutional approach - school that proposes that the management by the workers and its success depend on the construction of its internal features.

The definition of self-management, according to each of these schools, will not be the focus of this study. Not least because, as Nascimento (no date) claims, a theoretical definition of the term will always be incomplete unless it comes along with solid historical references.
For that reason, in order to outline the conceptual debate on self-management in this work, the inverse path was chosen. Questions that could contribute to the assessment of the management processes found in the companies were selected from the database produced by the national mapping of Brazilian WRCs. Then these questions were grouped in six themes or criteria for analysis of the experiences, listed below:

- Link with movements and/or principles;

- Opening for new partners;

- Payment difference;

- Elements of the work organization;

- Collective participation in the areas of power.

Only then the available literature was searched about the parameters for analysis of these criteria theme, or, its relation with a concept (or several concepts) of self-management.

\section{Link with movements and/or principles}

We understand as link with movements and/or principles the WRCs relationship with the world or with the society, in several spheres. Their commitments, their reciprocal responsibility, solidarity with the surrounding community and with the global community. Their engagement in social movements that express the workers' fights, or that express principles of values, such as solidarity, self-management, social justice and respect towards the ecosystems.

The concept of self-management is historically linked with experiences such as:

"[...] the heroic experience of the Commune of Paris (1871). The Soviets of working delegates and farmers and soldiers in Russia from 1905 to 1917. In Spain, after 1936, we had self-management practices. The Hungarian Republic of the worker councils, which existed between 1918 and 1919. In the post war period, in Yugoslavia in 1950 , a self-management based system was institutionalized. In Hungary and Poland, the worker councils appeared in the revolution of 1956. In Czechoslovakia in 1968, the Spring of Prague, thousands of worker committees appeared in the process of company management. In Portugal, with the carnation revolution, the worker commissions bloomed. In Latin America and Africa, since the Libertarian Republic establishment in Mexico, in 1911, until the Cuban (1959) 
and Nicaraguan (1979) revolutions, in many critical times of social fight, the workers and farmers materialized the idea of self-management and people's power." (Nascimento, 2014)

These experiences gave life to Marx's proclamation that "workers' emancipation will be the workers' own work". Their protagonists were workers and farmers who, in many parts of the planet, questioned the work relation of subordination to capital. In them, a new society organization model was experienced, based on the association of free and equal workers.

Nascimento (2014) retrieves the self-management concept formulated by the Portuguese workers in the $1^{\text {st }}$ National Conference for the Self-Managing Socialism.

"Self-management is the permanent construction of a model of Socialism, in which the many power levers, the decision, management and control centers, and the social, political and ideological productive mechanisms are in the workers-citizens' hands, who are organized freely and democratically, in associative forms created by the workers-citizens, based on the principle that all the organization should be structured from the basis to the summit and from the periphery to the center, in which the experience of direct democracy, free election and revocation is deployed, at any time of the decisions, the positions and agreements". [cf. $1^{\text {st }}$ National Conference for the Self-Management Socialism. Lisbon, May 1978].

This means that self-management is not limited to the realm of the production unit, but it comprehends all the spheres of society - the global production and all life realms self-management. Guillerm et Bourdet (1976) assert that self-management is a radical transformation, not only economical, but political, in the sense that it destroys the common notion of politics [as management reserved to a class of politicians] to create a new meaning for the word politics, i.e. management, without intermediaries and in all levels, of all the society, by all the men.

This retrieval allows us to consider that the WRCs that showed more participation, commitment, engagement with the surrounding community, workers movements and other self-management experiences are closer to a historically built concept of self-management than those that do not show such engagement.

\section{Opening for new partners}

The concept of self-management brings the weight of a historical fight against work relation of subordination to cap- ital, waged by experiences of associations of free and equal workers. Benini (2012) asserts that this subordination logic reversion must go through the questioning of one of the structuring elements of this logic: the private property of the means of production.

The opening for new partners represents one step in the sense of collective or community ownership of the means of production. Today the worker-recovered companies in Brazil and in Argentina are mostly formalized as Production Cooperatives. This legal form grants the right of ownership of the company to all the workers associated or cooperated with it. In this way, it is possible to assert that, at some level, they are all already breaking up with the logic of private property. However, if these cooperatives are not open to incorporating new partners, this form of ownership is little different from a traditional hetero-managed company, which may be shared by a group of owner partners. The idea of collective or community ownership goes beyond the form of shared private property. They assume a company that is open to the community, for other workers' equal participation.

\section{Payment difference}

In the self-management perspective, another issue that appears as a fundamental matter is about the forms and criteria of payment. In order to break up with the classic capitalist form of work organization it is necessary to review the forms of payment that consider work as a mere merchandise (Schwartz, 1996). We understand that work is more than that.

Measuring work value is not an easy task. Dejours (2008) says that every work has an invisible face, which is impossible to measure. Before this impossibility, the traditional companies assign the work value from the work market. In other words, the functions that are less available in the market earn more, and those that abound in offer have a worse payment.

In self-management, it is necessary to seek doing differently. Before the impossibility of measuring and fully assessing the work, the decisions in terms of payments are made collectively, by confronting the different points in sight.

\footnotetext{
"Another aspect in which solidarity differs cooperative from capitalist company is the scale of payments. To start, it is decided by each associate's individual vote. As just a minority fits in the pyramid payment top, it is natural that the gap between the biggest and the smallest payment is much smaller in the cooperative than in the capitalist company. This smaller difference in cooperatives is produced mainly by the fact that
} 
their executives are satisfied with much smaller payments than the ones in the capitalist congeners. It is on solidarity towards the other workers that the managers of big solidary companies are willing to earn much less than they could earn in non-solidary companies." (Singer, 2001)

The distributions of withdrawals in the cooperatives vary for each case. There are companies where the workers earn the same amount. There are companies where the difference between the largest wage and smallest wage is smaller and companies where these differences are quite expressive. This will be a criterion for us to check if the experiences get farther or closer to self-management.

\section{Elements of the work organization and Collective participation in the areas of power}

Ruggeri (2009) defines self-management in the context of WRCs as

\begin{abstract}
"Worker-management over a business unit without capitalists (owners) and managers and developing their own work organization, under non-hierarchical forms. In other words, self-management means that the workers impose collectively the norms that rule production, the work process organization, use of surplus, and the relationship with the remaining economy and society." (Ruggeri, 2009)
\end{abstract}

Araujo (2009) proposes an idea of work and production self-management from a review of the autonomy concept. In this interpretation, the author points the forms of control and mechanisms used as one of the elements that should be taken into consideration in the production self-management experiences. According to that review, the collective must decide about the forms of discipline and work control and everyone must play their role in exercising mutual control. This results in transformations in the forms of work organization that allow for all the workers' egalitarian participation in the decision processes, besides egalitarian sharing of power and the responsibilities implicated in the business management.

Based on these references, the WRCs analysis considered that the experiences that featured more internal democracy, non-hierarchical forms of management, collective control over the work process, are moving toward self-management, whereas the others move in the opposite direction.

Furthermore, we saw that information sharing and concern in terms of the workers training/education for participating in the collective management processes are elements of the work organization that can reveal more propensity to self-management. They are also important bases for egalitarian power sharing and internal democracy.

Once more, retrieving the concept of management presented by Araujo (2009), it is pointed out that, in order to be the protagonist of self-management work and production processes, individuals must have a social training and education, which allows for their qualified participation in the business management. This is not only about technical or management training, but also and especially a self-management-oriented political training.

\section{METHODOLOGY}

The bibliographic review about the concept of self-management presented above allowed identifying criteria for assessment of self-management in WRCs. However, that is not enough to assess the companies researched by the national mapping. It is necessary to search the produced database for information that relate to these criteria and build a model for dealing with that information.

In order to achieve this objective, we opted for the Multi-Criteria Decision Support (MCDS). This approach has as its focus the analysis of several alternatives (the recovered companies) under several criteria (self-management indicators). The proposal is to classify the alternatives from the best to the worst according to the support of multiple criteria. In this case, however, it is preferable not to treat as "better" and "worse", but identify the companies where, as a principle, self-management is more present or less present.

The multi-criteria approach is very often used for choosing an alternative as the most suitable according to several defined criteria. However, studies developed by Freitas et Costa (1998), Mansur et Costa (2000), Costa, Soares et de Oliveira (2004) and Costa, Mansur, Freitas et de Carvalho (2007) have shown MCDS potentiality for classifying services in an ordering scale, suggesting a position and class for each service.

The choice for MCDS for problems of quality in services was due to the presence of multiple subjective variables, which can be masked with the use of weighted average. That also occurs with the problem of classifying the recovered companies regarding self-management.

"It is acknowledged that this problem involves subjective variables that demand specific methodologies for addressing this category of variables. (...) the Multi-Criteria Analysis (MCDM) methods are more effective in addressing prioritization and ordering problems, involving multiple subjective variables. This fact shows that the use of MCDM methodologies is more recom- 
mendable for addressing this kind of problem, when compared with the use of weighted average." (Mansur et Gomes, 2000)

Although the studies already performed using this approach present good results with the use of these methods, Costa, Soares et de Oliveira (2004) mentioned that "the diffusion of the modeling of this kind of problem using such tools is not seen in the literature."

Here the multi-criteria approach will be applied for classifying the WRCs according to their forms of management as closer or less close to self-management. It is in a similar way to what was proposed for service classification.

The figure below represents the way as this classification is done.

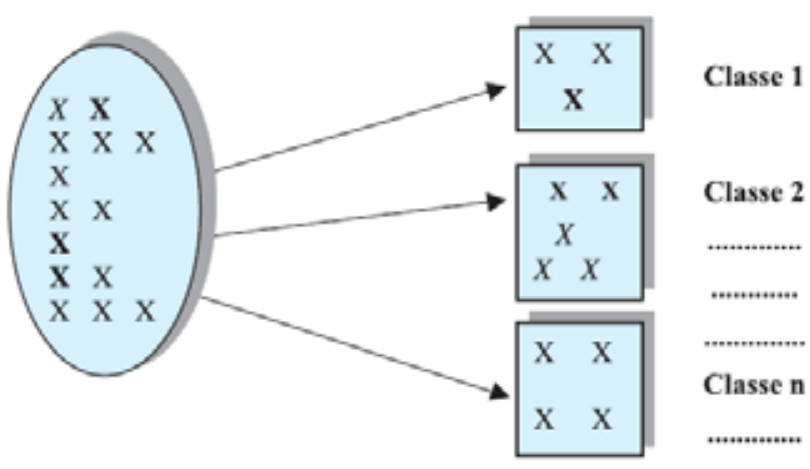

Figure 1. Ordered Classification Problem.

Source: Costa, Mansur, Freitas et De Carvalho, 2007.

In the universe of data about WRCs, we will classify the companies in three classes: Class A - Closer to Self-Management; Class B - Undefined; Class C - Far from Self-Management.

In order to rank the WRCs we used the De Borda method. In the De Borda method, the evaluation is done for each criterion, assigning each of them with a score related to their position in the criterion ranking. In the end, the scores assigned to each criterion are added and from that addition, a final ranking is generated (Costa, Soares et Oliveira, 2004).

We present below the steps performed by the research until coming to this classification of WRCs. We were inspired by the works of Costa, Mansur et Freitas (2007) and Costa, Soares et De Oliveira (2004), for elaborating these steps.

1. Identify and characterize the problem: identify the WRCs to be classified resorting to the database created by the national mapping of WRCs and the criteria defined from reviewing the concept of self-management.
2. Specify the criteria: identification of which "questions" asked by the time of the mapping may be used for assessing each of the criteria.

3. Specify the scale for the weight judgments of each criterion: assign weights to each criterion in the categorization of self-management.

4. Specify the form of self-management judgments at the light of each criterion: the forms of analysis of each question are created.

5. Emit value judgment at the light of each criterion: each WRC will be assessed according the form of judgment defined for each criterion. That assessment will form a set of spreadsheets for each criterion with the results of all the WRCs.

6. Identify the classes of equivalence along with their respective limits: in this step, the classes for each criterion that will be the pattern for classifying the WRCs will be established.

7. Perform the De Borda method: from the judgment of each criterion for each WRC and the definition of classes for each criterion, the WRCs will be ranked, as closer to self-management or farther from self-management. After each of the analyzed criterion, the order of the companies regarding each criterion will be added defining the final position of each WRC.

8. Analyze the results obtained by the classification: after performing the De BORDA method and elaborating the final spreadsheet, generating the classification of companies according to their forms of management, the results will be submitted to analysis performed by experts in order to check their liability.

Finally, before passing to this work results, it is necessary to acknowledge its limitations. It is convenient to point out that the database produced by the national mapping of WRCs originates from an essentially quantitative research, and therefore it has limitations regarding its ability to generate analysis on the management processes experienced in the companies. Qualitative approach researches, focused on each company's particular cases, and not on their universe (such as the mapping was), may reveal other aspects of self-management in the companies and thus complement the following analysis.

We acknowledge that classifying the WRCs as farther from the ideal of self-management, or closer based on quantitative data is a very difficult exercise. Self-management is a complex social phenomenon. However, we also acknowl- 
edge the necessity of thinking forms of assessing these experiences in a wide scale, considering that one day they may be more numerous, making it difficult to analyze each case individually. This is the sense in which the exercise of this article becomes important.

\section{RESULTS AND DISCUSSION}

Next, the results for each of the steps described above are presented.

\section{Identify and characterize the problem}

The criteria for assessing self-management, discussed in the conceptual review that will be considered for classifying the WRCs are: Link with the movements and/or principles; Opening for new partners; Work organization elements; Payment difference and; Collective participation in the areas of power.
In addition to these, Self-declaration was also considered as a "criterion" for assessing the companies. Actually, this is not a new criterion, but just an interpretation of the answers provided by the companies for a question of the mapping that asked them for a self-assessment in terms of the self-management processes. As presented ahead, these answers contribute to analyze the collective participation in the areas of power.

From the database that makes a total of 67 companies, the 52 that were visited and interviewed by the national mapping team were highlighted. These 52 WRCs were analyzed concerning the defined criteria. In order to preserve the companies' identity, they were called WRC1, WRC2, WRC3 [...] WRC52.

It is noteworthy that few companies had valid answers to all the questions considered in the analysis. Some present more valid answers, and others present less, what may cause slight distortions in the results.

Table 1. Specification of the self-management criteria - selection of questions from the questionnaire

\begin{tabular}{|c|c|c|c|}
\hline Criterion & $\begin{array}{l}\text { Bibliographic } \\
\text { reference }\end{array}$ & Questionnaire Question & No. \\
\hline \multirow{7}{*}{$\begin{array}{l}\text { Link with } \\
\text { movements } \\
\text { and/or prin- } \\
\text { ciples }\end{array}$} & \multirow{7}{*}{$\begin{array}{l}\text { Nascimento } \\
\text { (no date), } \\
\text { Guillerm } \\
\text { et Bourdet } \\
(1976)\end{array}$} & Which supports did they have during the recovery process? & 7 \\
\hline & & $\begin{array}{l}\text { Did they establish any kind of economic and/or political tie with other recovered compa- } \\
\text { ny(ies) or solidarity economic undertakings? }\end{array}$ & 85 \\
\hline & & $\begin{array}{l}\text { Do they have any relation with or participate in any kind of social movement, political party } \\
\text { or group? }\end{array}$ & 86 \\
\hline & & $\begin{array}{c}\text { Regarding solidarity economy, do they have any contact with organizations that work on this } \\
\text { theme? }\end{array}$ & 87 \\
\hline & & $\begin{array}{c}\text { Does or did their company belong to any movement or organization of recovered companies } \\
\text { or cooperatives? }\end{array}$ & 88 \\
\hline & & $\begin{array}{l}\text { In the workers' view, what is the company's role towards the surrounding community? Have } \\
\text { they carried out any kind of solidarity or cultural activity? }\end{array}$ & $\begin{array}{c}89 \text { and } \\
90\end{array}$ \\
\hline & & $\begin{array}{l}\text { Did they take part in any participative instance of the State (e.g. Council, Commissions, Con- } \\
\text { ferences)? }\end{array}$ & 97 \\
\hline \multirow{2}{*}{$\begin{array}{l}\text { Openings } \\
\text { for New } \\
\text { Partners }\end{array}$} & \multirow[t]{2}{*}{ Benini (2012) } & $\begin{array}{c}\text { What is the current number of workers? How many are partners/cooperates and how many } \\
\text { are hired? }\end{array}$ & 19 \\
\hline & & Have partner-workers been incorporated since the recovery until now? & 25 \\
\hline \multirow{3}{*}{$\begin{array}{l}\text { Work Or- } \\
\text { ganization } \\
\text { Elements }\end{array}$} & \multirow{3}{*}{$\begin{array}{c}\text { Araujo } \\
\text { (2010), Rug- } \\
\text { geri (2009) }\end{array}$} & Do they keep the same work organization present in the original company? & 32 \\
\hline & & $\begin{array}{c}\text { Do they have sector supervisors or coordinators? With which criteria are they chosen or } \\
\text { appointed? }\end{array}$ & $35 c$ \\
\hline & & Are there any training processes supported or developed by the company for the workers? & $36 a$ \\
\hline $\begin{array}{l}\text { Payment } \\
\text { Difference }\end{array}$ & Singer (2001) & $\begin{array}{l}\text { Which are the company's payment ranges (amounts of biggest and smallest wage/withdraw- } \\
\text { al)? }\end{array}$ & 41 \\
\hline \multirow{2}{*}{$\begin{array}{c}\text { Collective } \\
\text { participation } \\
\text { in the areas } \\
\text { of power }\end{array}$} & \multirow{2}{*}{$\begin{array}{c}\text { Araujo } \\
\text { (2010), Rug- } \\
\text { geri (2009) }\end{array}$} & Regarding the Board of Directors, do they keep the positions for more than one term? & 47 \\
\hline & & Do they hold general assemblies/meetings periodically? How often? & 51 \\
\hline \multirow{2}{*}{$\begin{array}{l}\text { Self-declara- } \\
\text { tion }\end{array}$} & \multirow{2}{*}{$\begin{array}{c}\text { Araujo } \\
\text { (2010), Rug- } \\
\text { geri (2009) }\end{array}$} & Do they see themselves as working under the self-management form? Why? & 54 \\
\hline & & $\begin{array}{l}\text { Which are the main changes they consider to have happened in the company after the recov- } \\
\text { ery? }\end{array}$ & 101 \\
\hline
\end{tabular}




\section{Specify the criteria}

The authors of this article analyzed the questionnaire that generated the mapping database and identified this questionnaire questions that allowed assessing each of the criteria. Table 1 below shows for each criterion the questions that were used for analysis.

\section{Specify the scale for the judgments of each criterion weights}

In order to define the criteria weights, a 100 sum was sought - maximal score a WRC could reach. First, each criterion weight was given, and then the criterion total weight was distributed through the questions pertinent to it.

That first weighting generated an analysis of the cases, which was evaluated by an expert. The experts found incoherencies in the weighting and suggested changes. Once the changes were made, the following weight distribution was achieved - which now add a maximal score of 98.5.

It is important to mention that the weights assigned consider not only how important the question is to the self-management processes analysis according to the experts' judgment. These weights also consider an assessment of the researchers in terms of the available data quality/liability. For example, the criterion Work Organi- zation Elements could have a bigger weight if the available data allowed for a better analysis of the work organization in the WRCs. However, as previously pointed out, the national mapping of WRCs was an essentially quantitative approach research, which has limitations concerning its analysis ability on the forms of work organization.

\section{Specify the form of self-management judgments in the light of each criterion.}

In the tables below the forms of judgment for each criterion question will be described. The description of the form of judgment is necessary, as the interpretation of the database results are not always obvious.

\section{Emit judgment of value at the light of each criterion}

In this step, the answers obtained in the interviews from each mapped WRC were assessed according to the form of judgment established above. The answer assessment generated table 9 , containing the scores obtained by each company in each of the questions.

The score obtained by the companies in each question was multiplied by the weight in concern, and the products of those multiplications were added in each criterion, generating a total score for each company per criterion.

Table 2. Scale for the judgments

\begin{tabular}{|c|c|c|c|c|}
\hline Criterion & $\begin{array}{l}\text { General } \\
\text { Weight }\end{array}$ & Questionnaire Question & No. & Weight \\
\hline \multirow{7}{*}{$\begin{array}{l}\text { Link with movements and/or Prin- } \\
\text { ciples (C1) }\end{array}$} & \multirow{7}{*}{22.5} & Which supports? & 7 & 1.5 \\
\hline & & $\begin{array}{l}\text { Do they establish any kind of link with WRCs or Economy } \\
\text { Undertakings? }\end{array}$ & 85 & 1.5 \\
\hline & & Do they have relation with any social movement? & 86 & 1.5 \\
\hline & & Contact with Ecosol & 87 & 1.5 \\
\hline & & Were they in some WRCs movement? & 88 & 3 \\
\hline & & Relation with the community & 89 and 90 & 10 \\
\hline & & Take part in some participative instance & 97 & 3.5 \\
\hline \multirow{2}{*}{ Openings for New Partners (C2) } & \multirow{2}{*}{20} & Partners/Hired Ratio & 19 & 15 \\
\hline & & Did they incorporate new partner workers? & 25 & 5 \\
\hline \multirow{3}{*}{ WO Elements (C3) } & \multirow{3}{*}{15} & Which changes did they introduce into the WO? & 32 & 3.5 \\
\hline & & Criteria to choose supervisors & $35 c$ & 8.5 \\
\hline & & Political and cooperativism training courses & $36 a$ & 3 \\
\hline Difference in payment (C4) & 15 & Ratio between the biggest and smallest wages & 41 & 15 \\
\hline \multirow{2}{*}{$\begin{array}{l}\text { Collective participation in the } \\
\text { areas of power (C5) }\end{array}$} & \multirow{2}{*}{15} & Board of Directors is modified & 47 & 5 \\
\hline & & Hold periodic assemblies & 51 & 10 \\
\hline \multirow{2}{*}{ Self-declaration (C6) } & \multirow{2}{*}{10} & Self-Management Concept & 54 & 2.5 \\
\hline & & Main changes since recovery & 101 & 7.5 \\
\hline
\end{tabular}


Table 3. Forms of judgment for the criterion "Tie with movements or principles"

\begin{tabular}{|c|c|c|}
\hline Criterion & Questionnaire Question & Form of Judgment \\
\hline \multirow{7}{*}{$\begin{array}{l}\text { Link with move- } \\
\text { mentsand/or } \\
\text { Principles }\end{array}$} & $\begin{array}{l}\text { Which supports did they have during the } \\
\text { recovering process? }\end{array}$ & $\begin{array}{l}\text { The following supports were considered significant to establish ties } \\
\text { with the principles of cooperativism and self-management: ANTEAG, } \\
\text { Unions, UNISOL, and the community around the company. } \\
\text { The WRCs that mentioned some of these supports got } 1 \text { point in this } \\
\text { question. The ones that did not mention any did not get any points } \\
\text { here. }\end{array}$ \\
\hline & $\begin{array}{c}\text { Was some kind of economic and/or political } \\
\text { tie established with other recovered com- } \\
\text { pany (ies) or economic solidarity undertak- } \\
\text { ings? }\end{array}$ & $\begin{array}{l}\text { Answer } \mathrm{YES}=1 \text { points } \\
\text { Answer NO }=0 \text { points }\end{array}$ \\
\hline & $\begin{array}{l}\text { Do they have any relation with or do they } \\
\text { participate in any kind of social movement, } \\
\text { political party or group? }\end{array}$ & $\begin{array}{l}\text { Answer } \mathrm{YES}=1 \text { points } \\
\text { Answer NO }=0 \text { points }\end{array}$ \\
\hline & $\begin{array}{l}\text { Regarding solidarity economy, do they have } \\
\text { any contact with organizations that work on } \\
\text { this theme? }\end{array}$ & $\begin{array}{l}\text { Answer } \mathrm{YES}=1 \text { points } \\
\text { Answer NO }=0 \text { points }\end{array}$ \\
\hline & $\begin{array}{c}\text { Does or did their company belong to any } \\
\text { movement or organization of recovered } \\
\text { companies or cooperatives? }\end{array}$ & $\begin{array}{l}\text { Answer } \mathrm{YES}=1 \text { points } \\
\text { Answer NO }=0 \text { points }\end{array}$ \\
\hline & $\begin{array}{c}89 \text { - In the workers' view, what is the } \\
\text { company's role towards the surrounding } \\
\text { community? } \\
90 \text { - Did they perform any kind of solidarity } \\
\text { or cultural activity? }\end{array}$ & 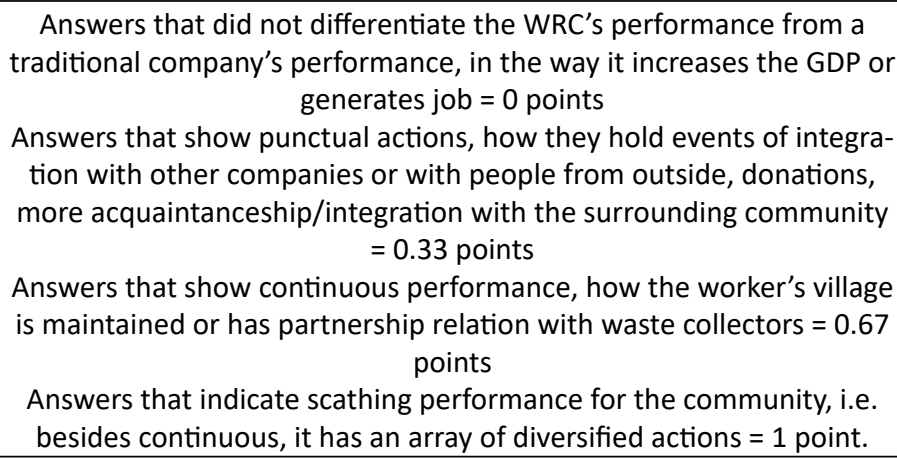 \\
\hline & $\begin{array}{l}\text { Did they take part in any participative } \\
\text { instance of the State (e.g. Council, Commis- } \\
\text { sions, Conferences)? }\end{array}$ & $\begin{array}{l}\text { Answer } \mathrm{YES}=1 \text { points } \\
\text { Answer NO }=0 \text { points }\end{array}$ \\
\hline
\end{tabular}

Table 4: Forms of judgment for the criterion "Opening for new partners"

\begin{tabular}{|c|c|c|}
\hline Criterion & Questionnaire Question & Form of Judgment \\
\hline \multirow{2}{*}{$\begin{array}{c}\text { Openings for } \\
\text { New Partners }\end{array}$} & $\begin{array}{c}\text { What is the current number of workers who } \\
\text { are partners/cooperates, and hired? }\end{array}$ & $\begin{array}{c}100 \% \text { of workers as partners/cooperates is preferable. The smaller the } \\
\text { percentage, the worse the company's rating. Score in continuous scale } \\
\text { from 0 to 1 according to the proportion between partners/cooperates } \\
\text { and hired workers }\end{array}$ \\
\cline { 2 - 3 } & $\begin{array}{c}\text { Have any partner workers been incorporat- } \\
\text { ed since the recovery until now? }\end{array}$ & $\begin{array}{c}\text { Answer NO }=0 \text { points } \\
\text { Answ points was considered for some NO answers that show reasonable } \\
\text { justifications such as, for example: nobody wants to enter an indebted } \\
\text { company, a new company that has not had time to incorporate new } \\
\text { partners yet. }\end{array}$ \\
\hline
\end{tabular}


Table 5. Forms of judgment for criterion "Work organization elements"

\begin{tabular}{|c|c|c|}
\hline Criterion & Questionnaire Question & Form of Judgment \\
\hline \multirow{3}{*}{$\begin{array}{l}\text { Work Organiza- } \\
\text { tion Elements }\end{array}$} & $\begin{array}{c}\text { Do they keep the same work organization } \\
\text { present in the original company? }\end{array}$ & $\begin{array}{l}\text { Answer YES }=1 \text { point } \\
\text { Answer } \mathrm{NO}=0 \text { points }\end{array}$ \\
\hline & $\begin{array}{l}\text { With which criteria do they choose or } \\
\text { appoint the sectors supervisors or coordi- } \\
\text { nators? }\end{array}$ & $\begin{array}{c}\text { Answer decision in assembly or by election = } 1 \text { point } \\
\text { Answer former owner (company before recovery) or the WRC board } \\
\text { of directors' choice }=-1 \text { point }\end{array}$ \\
\hline & $\begin{array}{l}\text { Are there any training processes support- } \\
\text { ed or developed by the company for the } \\
\text { workers? }\end{array}$ & $\begin{array}{l}\text { The WRCs that mentioned the implementation of political or coopera- } \\
\text { tivism/self-management training courses got } 1 \text { point in this question. }\end{array}$ \\
\hline
\end{tabular}

Table 6. Forms of judgment for the criterion "Payment difference"

\begin{tabular}{|c|c|c|}
\hline Criterion & Questionnaire Question & Form of Judgment \\
\hline $\begin{array}{c}\text { Payment Differ- } \\
\text { ence }\end{array}$ & $\begin{array}{c}\text { Which are the company's payment ranges } \\
\text { (values of biggest and smallest wage/with- } \\
\text { drawal)? }\end{array}$ & $\begin{array}{c}\text { The bigger the difference between the payments, the worse the com- } \\
\text { pany's rating. Score in continuous scale from } 0 \text { to } 1 .\end{array}$ \\
\hline
\end{tabular}

Table 7. Forms of judgment for the criterion "Collective participation in the areas of power"

\begin{tabular}{|c|c|c|}
\hline Criterion & Questionnaire Question & Form of Judgment \\
\hline \multirow[b]{2}{*}{$\begin{array}{l}\text { Collective par- } \\
\text { ticipation in the } \\
\text { areas of power }\end{array}$} & $\begin{array}{l}\text { Regarding the Board of Directors, do they } \\
\text { keep the positions for more than one } \\
\text { term? }\end{array}$ & Answer "some positions were never changed" = -1 point \\
\hline & $\begin{array}{l}\text { Did they hold general assemblies/meetings } \\
\text { periodically? How often? }\end{array}$ & $\begin{array}{c}\text { Weekly, fortnightly or monthly assemblies frequency = } 1 \text { point } \\
\text { Bimonthly, quarterly or four-monthly frequency }=0.75 \text { points } \\
\text { Semiannual frequency }=0.5 \text { points } \\
\text { Yearly frequency }=0 \text { points } \\
\text { Note: it is pointed out that almost all the companies researched } \\
\text { assume the legal form of cooperative. Moreover, by the law, every } \\
\text { cooperative must hold at least one annual assembly. }\end{array}$ \\
\hline
\end{tabular}

Table 8. Forms of judgment for the criterion "Self-declaration"

\begin{tabular}{|c|c|c|}
\hline Criterion & Questionnaire Question & Form of Judgment \\
\hline \multirow[t]{2}{*}{ Self-declaration } & $\begin{array}{l}\text { Do they see themselves as working under } \\
\text { the self-management form? Why? }\end{array}$ & $\begin{array}{l}\text { Almost all the WRCs declared that they work in a self-managed way. } \\
\text { The ones that did not declare themselves as self-managed had justifi- } \\
\text { cations that showed a struggle for self-management. } \\
\text { Analyzing the interviewees' speech, } 4 \text { cases were found, where the } \\
\text { concept of self-management expressed in the interviews appeared to } \\
\text { be very contradictory: A - "they participate, but not directly"; B - "we } \\
\text { make decisions that the group has applauded, we manage with ex- } \\
\text { tensive powers"; C - "the union decides with the board of directors"; } \\
\text { D - "they participate, but in a small way, in the administrative issues". } \\
\text { Because of these answers, those companies got zero points in the } \\
\text { "criterion" self-declaration. } \\
\text { The other companies got } 1 \text { point. }\end{array}$ \\
\hline & $\begin{array}{c}\text { Which are the main changes they consider } \\
\text { to have happened in the company after } \\
\text { the recovery? }\end{array}$ & $\begin{array}{c}\text { Answers that do not show changes in the form of management }=0 \\
\text { points } \\
\text { Answers that show more worker participation, a space where people } \\
\text { are listened to, or are more aware of the decisions }=0.5 \text { points } \\
\text { Answers that highlight the management of } / \text { by the workers, collective } \\
\text { management, collective appropriation of the areas of decision and } \\
\text { power }=1 \text { point }\end{array}$ \\
\hline
\end{tabular}


Table 9. Score per WRC per Question

\begin{tabular}{|c|c|c|c|c|c|c|c|c|c|c|c|c|c|c|c|c|c|}
\hline Criterion & \multicolumn{7}{|c|}{$\mathrm{C} 1$} & \multicolumn{2}{|c|}{ C2 } & \multicolumn{3}{|c|}{ C3 } & $\mathrm{C4}$ & \multicolumn{2}{|c|}{$\mathrm{C5}$} & \multicolumn{2}{|c|}{ C6 } \\
\hline Weight & 1.5 & 1.5 & 1.5 & 1.5 & 3 & 10 & 3.5 & 15 & 5 & 3.5 & 8.5 & 3 & 15 & 5 & 10 & 2.5 & 7.5 \\
\hline Question & 7 & 85 & 86 & 87 & 88 & $89 / 90$ & 97 & 19 & 25 & 32 & $35 c$ & $36 a$ & 41 & 47 & 51 & 54 & 101 \\
\hline WRC1 & 1 & 0 & 1 & 1 & 1 & 0.3 & 1 & 1.00 & 1 & & 0 & 1 & 1.00 & 0 & 1 & 1 & 0 \\
\hline WRC2 & 1 & 1 & 1 & 1 & 1 & 1 & 1 & 1.00 & 1 & 0 & 0 & 0 & 0.67 & 0 & 1 & 1 & 0 \\
\hline WRC3 & 1 & 0 & 1 & 1 & 0 & 0.3 & 1 & 1.00 & 1 & 1 & 1 & 0 & 0.50 & 0 & 1 & 1 & 0 \\
\hline WRC4 & 0 & 1 & 0 & 0 & 0 & 0 & 1 & 1.00 & 1 & 0 & & 0 & 0.60 & 0 & 1 & 1 & 0.5 \\
\hline WRC5 & & 1 & 1 & & 1 & 1 & 0 & 1.00 & 1 & & 0 & 1 & 0.30 & 0 & 1 & 1 & \\
\hline WRC6 & 1 & 1 & 1 & 1 & 1 & 0 & 1 & 1.00 & & 1 & 1 & 1 & 0.45 & 0 & 1 & 0 & 0 \\
\hline WRC7 & 1 & 1 & 1 & 1 & 1 & 0 & 1 & 1.00 & 1 & 1 & 0 & 1 & 0.41 & 0 & 1 & 1 & 0 \\
\hline WRC8 & 1 & 0 & 0 & 0 & 0 & 0 & & 0.83 & 1 & 0 & 1 & 0 & 0.75 & 0 & 1 & 1 & 0.5 \\
\hline WRC9 & 1 & 1 & 0 & 1 & 1 & 0 & 1 & 1.00 & 1 & & & 0 & 0.80 & 0 & 0.8 & 1 & 0 \\
\hline WRC10 & & 0 & 0 & & 0 & 0 & & 1.00 & 1 & & & 0 & 0.32 & -1 & 1 & 1 & 0 \\
\hline WRC11 & 1 & 1 & 0 & 1 & 1 & 0 & 0 & 1.00 & 1 & 0 & -1 & 1 & 1.00 & 0 & 0.8 & 0 & 0 \\
\hline WRC12 & & 1 & 1 & 1 & 1 & 1 & 0 & 1.00 & 1 & 1 & 1 & 1 & 0.25 & 0 & 0.5 & 1 & 0.5 \\
\hline WRC13 & 1 & 1 & 1 & 1 & 1 & 0 & 1 & 0.80 & 1 & 1 & -1 & 1 & 0.25 & 0 & 1 & 1 & \\
\hline WRC14 & 0 & 1 & & 1 & 0 & & & 0.50 & 1 & 1 & -1 & 0 & 1.00 & 0 & 1 & 1 & \\
\hline WRC15 & 1 & 1 & 1 & 1 & 1 & 1 & 1 & 1.00 & 1 & 1 & 0 & 1 & 0.14 & 0 & 1 & 1 & 0 \\
\hline WRC16 & 1 & 1 & 0 & 0 & 1 & 0.3 & 1 & 0.71 & 1 & & 1 & 1 & 0.30 & 0 & 1 & 1 & \\
\hline WRC17 & 1 & 1 & 1 & 1 & 1 & 0 & 1 & 0.86 & 1 & 1 & & 0 & 0.74 & 0 & 0 & 1 & 0.5 \\
\hline WRC18 & 1 & 1 & 0 & 1 & 1 & 0.3 & 1 & 0.80 & 1 & & -1 & 0 & 0.30 & 0 & 0.8 & 1 & 1 \\
\hline WRC19 & 1 & 1 & & 0 & 1 & 0 & 1 & 0.60 & 0 & 0 & & 0 & 0.69 & 0 & 1 & 1 & \\
\hline WRC20 & & 1 & 1 & 1 & 1 & 0 & 0 & 1.00 & 1 & & 0 & 1 & 0.15 & 0 & 1 & 1 & 0.5 \\
\hline WRC21 & & 1 & 0 & 1 & 1 & 0 & 1 & 0.89 & 1 & 1 & 0 & 0 & 0.69 & 0 & & 1 & 0 \\
\hline WRC22 & 0 & 1 & 0 & 1 & 1 & 0 & 1 & 0.75 & 1 & 1 & & 0 & 0.54 & 0 & 0 & 1 & 1 \\
\hline WRC23 & 0 & 1 & 1 & 1 & 1 & 0.3 & 0 & 0.99 & 1 & 0 & & 1 & 0.21 & 0 & 0.8 & 1 & 0 \\
\hline WRC24 & 1 & 0 & 0 & 0 & 0 & 0 & 1 & 1.00 & 1 & 0 & & 0 & 0.36 & 0 & 0 & 1 & 0 \\
\hline WRC25 & & 0 & 0 & 0 & 0 & 0 & 1 & 1.00 & 1 & 1 & -1 & 0 & 0.38 & 0 & 0 & 1 & 0 \\
\hline WRC26 & 1 & 1 & 1 & 1 & 1 & 0.3 & 1 & 1.00 & 1 & 0 & 1 & 1 & 0.11 & -1 & 1 & 1 & 0.5 \\
\hline WRC27 & 1 & 1 & 1 & 1 & 1 & 0 & 1 & 1.00 & 1 & 0 & 0 & 1 & 0.28 & 0 & & 1 & \\
\hline WRC28 & 1 & 0 & 0 & 1 & 1 & 0 & 1 & 0.88 & 0 & 0 & & 0 & 0.43 & 0 & & 1 & \\
\hline WRC29 & & 0 & 0 & 1 & 1 & 0.3 & 1 & 0.56 & 1 & 0 & & 0 & 0.26 & 0 & 0.8 & 1 & \\
\hline WRC30 & 1 & & & & 1 & 1 & & 1.00 & 1 & 1 & -1 & 1 & 0.15 & 0 & 0 & 1 & \\
\hline WRC31 & 1 & 0 & 0 & 0 & 1 & 0.3 & & 0.43 & 1 & 1 & 0 & 0 & 0.25 & 0 & 0.8 & 1 & 0 \\
\hline WRC32 & 1 & 1 & 1 & 1 & 1 & 0.7 & 1 & 0.90 & 0 & 0 & -1 & 1 & 0.11 & 0 & 0.8 & 1 & 1 \\
\hline WRC33 & & 0 & 0 & & 1 & 0 & & 0.81 & & 0 & & 0 & 0.33 & 0 & 0 & 1 & 0 \\
\hline WRC34 & & 1 & 0 & 0 & 1 & 0 & 1 & 0.39 & 0 & 1 & 0 & 0 & 0.36 & 0 & 0.8 & 1 & 0 \\
\hline WRC35 & & 1 & 0 & 1 & 1 & 0 & 1 & 0.67 & 1 & 0 & -1 & 0 & 0.25 & 0 & 0.5 & 1 & 0.5 \\
\hline WRC36 & 0 & 1 & 0 & 0 & 0 & 0.3 & 1 & 0.71 & 0 & 1 & 0 & 0 & 0.12 & 0 & 1 & 1 & 0.5 \\
\hline WRC37 & & 0 & 1 & 0 & 1 & 0.7 & 1 & 0.41 & 1 & 0 & -1 & 0 & 0.31 & -1 & 0 & 1 & 1 \\
\hline WRC38 & & 1 & 1 & 1 & 1 & 0.3 & 1 & 0.68 & 1 & 1 & 0 & 1 & 0.17 & 0 & 0 & 1 & 0 \\
\hline WRC39 & & 1 & 1 & 1 & 1 & 0.3 & 1 & 0.41 & 1 & 1 & 0 & 1 & 0.24 & 0 & & 1 & 1 \\
\hline WRC40 & & 1 & 0 & 1 & 1 & 0 & 1 & 0.36 & 1 & 0 & 1 & 0 & 0.33 & 0 & 0 & 1 & 0 \\
\hline WRC41 & 1 & 0 & 0 & 0 & 1 & 0 & 1 & 0.84 & 1 & 1 & 0 & 0 & 0.15 & 0 & 0 & 1 & \\
\hline WRC42 & 0 & 1 & 0 & 1 & 1 & 0 & 1 & 0.70 & 1 & 1 & -1 & 0 & 0.16 & 0 & 0 & 1 & \\
\hline WRC43 & & 0 & 0 & 1 & 1 & 0 & 1 & 0.33 & 1 & 0 & 0 & 1 & 0.20 & 0 & 0.5 & 1 & 0 \\
\hline WRC44 & 0 & 0 & 0 & 0 & 0 & 0 & 1 & 0.31 & 1 & 1 & & 0 & 0.25 & 0 & 0 & 1 & 0 \\
\hline WRC45 & 0 & 0 & 0 & 0 & 0 & 0.3 & 1 & 0.36 & 1 & 1 & 0 & 0 & 0.10 & 0 & 1 & 1 & \\
\hline WRC46 & 1 & 1 & 0 & 0 & 1 & 0.3 & 1 & 0.37 & 1 & 0 & 0 & 0 & 0.13 & 0 & 0.8 & 1 & 0 \\
\hline WRC47 & 1 & 1 & 0 & 1 & 1 & 0 & 1 & 0.97 & 1 & 0 & & 0 & 0.10 & 0 & 0 & 1 & 0 \\
\hline WRC48 & & 1 & 0 & 1 & 1 & 1 & 0 & 0.46 & 1 & 1 & 0 & 1 & 0.09 & 0 & 1 & 1 & 0 \\
\hline WRC49 & & 1 & 1 & 0 & 1 & 0.3 & 0 & 0.61 & 1 & 1 & -1 & 0 & 0.12 & 0 & 0 & 1 & 0 \\
\hline WRC50 & & 1 & 0 & 1 & 1 & 1 & 0 & 0.00 & 1 & 1 & 1 & 0 & 0.13 & 0 & & 1 & \\
\hline WRC51 & 0 & 1 & 0 & 1 & 1 & 0.3 & 0 & 0.72 & 1 & 0 & & 1 & 0.08 & -1 & 0.5 & 0 & 0 \\
\hline WRC52 & & 1 & 0 & & 1 & 0.3 & & 0.04 & 0 & 0 & & 1 & 0.10 & 0 & 0.5 & 0 & 0.5 \\
\hline
\end{tabular}




\section{Identify the equivalence classes together with their respective limits}

The identification of the equivalence classes was performed considering each criterion separately. For defining the classes, upper and lower limits were created for each criterion (according to figure 2 below), which were called boundaries.

In order to define boundary values, initially the average points obtained by the set of companies were calculated in every criterion, and then the standard deviation was calculated. Then the average plus one standard deviation was calculated as B2 (upper boundary) and the average minus one standard deviation as B1 (lower boundary). This method, however, did not bring good results. Then, it was chosen to define the classes' boundaries following what would be more preferable for each criterion. The same group of experts that elaborated the weights for each criterion did that definition. The values for each of the tools in each of the criteria may be seen in table 10 below.

\section{Perform De BORDA method}

From every criterion score for each WRC and from the classes' definition, the companies were ranked by criterion, generating a value related to its position in the ranking. Every WRC position in the ranking ranged from 54 (best score) to 1 (worst score), so that, when there was a tie, the same position was assigned. The ranking went up to 54, because there were 52 WRCs and 2 Boundaries. The values related to position in the ranking were multiplied by each criterion total weight and the products of that multiplication were added, finally generating the company's total score. A final ranking of the WRCs was then given, considering the set of the evaluated criteria.

The maximal score that a company could obtain, in case it was the first in the ranking of all the six criteria, would be 4,524 points. The minimal score, in case the company was the last in all of the criteria, would be 98.5 points.

It is noteworthy that the colors inside the table indicate the WRCs' classification in each criterion. Blue indicates class $A$, yellow class $B$, and red class $C$.

Table 10. Definition of B1 and b2 boundaries for each criterion

\begin{tabular}{|c|c|c|c|c|c|}
\hline Criterion & Class A Specification & \begin{tabular}{|c|} 
B2 \\
Boundary \\
\end{tabular} & Class B Specification & \begin{tabular}{|c|} 
B1 \\
Boundary \\
\end{tabular} & Class C Specification \\
\hline $\begin{array}{l}\text { Link with move- } \\
\text { ments and/or } \\
\text { Principles }\end{array}$ & $\begin{array}{l}\text { Over } 65 \% \text { of the possible } \\
\text { points in this criterion }\end{array}$ & 14.625 & $\begin{array}{l}\text { between } 35 \% \text { and } 65 \% \text { of the } \\
\text { possible points for this criterion. }\end{array}$ & 7.875 & $\begin{array}{l}\text { less than } 35 \% \text { of the } \\
\text { points in this criterion }\end{array}$ \\
\hline $\begin{array}{l}\text { Openings for } \\
\text { New Partners }\end{array}$ & $\begin{array}{c}\text { Criterion maximal score, } \\
\text { i.e. it has } 100 \% \text { of partners } \\
\text { and is open for new } \\
\text { entrants }\end{array}$ & 19.99 & $\begin{array}{l}\text { are open for new partners and } \\
\text { have between } 50 \% \text { and } 99 \% \text { of } \\
\text { partners }\end{array}$ & 12.49 & Less than $50 \%$ of partners \\
\hline WO Elements & $\begin{array}{c}\text { Score equivalent or } \\
\text { superior to having elected } \\
\text { supervisors OR having per- } \\
\text { formed changes in the WO } \\
\text { AND having had political } \\
\text { training courses }\end{array}$ & 6.49 & $\begin{array}{l}\text { the companies that did not have } \\
\text { their supervisors appointed by } \\
\text { the board of directors or by the } \\
\text { previous administration, but also } \\
\text { did not meet the requirements } \\
\text { for fitting class A }\end{array}$ & -0.01 & $\begin{array}{l}\text { Companies that have their } \\
\text { supervisors appointed by } \\
\text { the board of directors or } \\
\text { by the previous adminis- } \\
\text { tration (negative score) }\end{array}$ \\
\hline $\begin{array}{l}\text { Payment Differ- } \\
\text { ence }\end{array}$ & $\begin{array}{l}\text { Difference between the } \\
\text { highest and the lowest } \\
\text { wage up to twice }\end{array}$ & 0.49 & $\begin{array}{c}\text { difference between the highest } \\
\text { and the lowest payment be- } \\
\text { tween } 2 \text { and } 5 \text { times }\end{array}$ & 0.19 & $\begin{array}{c}\text { difference between the } \\
\text { highest and the lowest } \\
\text { wages bigger than } 5 \text { times }\end{array}$ \\
\hline $\begin{array}{l}\text { Collective par- } \\
\text { ticipation in the } \\
\text { areas of power }\end{array}$ & $\begin{array}{c}\text { Holds assemblies at least } \\
\text { once a month and shifts } \\
\text { members in the Adminis- } \\
\text { trative Council }\end{array}$ & 9.9 & $\begin{array}{l}\text { Holds monthly assemblies, but } \\
\text { does not have any member shifts } \\
\text { in the Administrative Council } \\
\text { OR holds assemblies more often } \\
\text { than once a year and shift the } \\
\text { Administrative Council members }\end{array}$ & 0.1 & $\begin{array}{l}0 \text { points - that is, holds } \\
\text { yearly assemblies only } \\
\text { OR holds semiannual } \\
\text { assemblies AND does not } \\
\text { shift the Administrative } \\
\text { Council members }\end{array}$ \\
\hline Self-declaration & $\begin{array}{l}\text { Maximal score, i.e. coher- } \\
\text { ently declared Self-Man- } \\
\text { agement and featured } \\
\text { changes in the manage- } \\
\text { ment appropriation by the } \\
\text { workers collective. }\end{array}$ & 9.9 & $\begin{array}{c}\text { declared coherently the } \\
\text { Self-Management and show } \\
\text { more worker participation as a } \\
\text { change. }\end{array}$ & 6 & $\begin{array}{l}\text { score lower to than having } \\
\text { coherently declared } \\
\text { self-management and hav- } \\
\text { ing shown more worker } \\
\text { participation as a change }\end{array}$ \\
\hline
\end{tabular}


Table 11. The WRCs' final classification

\begin{tabular}{|c|c|c|c|c|c|c|c|c|}
\hline \multirow{2}{*}{$\begin{array}{c}\text { Final Classifi- } \\
\text { cation }\end{array}$} & \multirow{2}{*}{$\begin{array}{c}\text { Criterion } \\
\text { Weight }\end{array}$} & \multirow{2}{*}{$\begin{array}{c}\mathrm{C1} \\
22.5\end{array}$} & \multirow{2}{*}{$\begin{array}{l}\mathrm{C2} \\
20\end{array}$} & \multirow{2}{*}{$\begin{array}{l}\text { C3 } \\
15\end{array}$} & \multirow{2}{*}{$\begin{array}{l}\mathrm{C4} \\
15\end{array}$} & \multirow{2}{*}{$\begin{array}{l}\mathrm{C5} \\
15\end{array}$} & \multirow{2}{*}{$\begin{array}{l}\text { C6 } \\
10\end{array}$} & \multirow{2}{*}{ Final Score } \\
\hline & & & & & & & & \\
\hline 1 & WRC12 & 51 & 54 & 54 & 25 & 27 & 48 & 11416.00 \\
\hline 2 & WRC2 & 54 & 54 & 23 & 46 & 54 & 38 & 9967.00 \\
\hline 3 & WRC3 & 32 & 54 & 52 & 43 & 54 & 38 & 10336.00 \\
\hline 4 & WRC7 & 37 & 54 & 46 & 39 & 54 & 38 & 10167.00 \\
\hline 5 & B2 & 46 & 40 & 41 & 42 & 37 & 49 & 10186.00 \\
\hline 6 & WRC15 & 54 & 54 & 46 & 12 & 54 & 38 & 10359.00 \\
\hline 7 & WRC5 & 50 & 54 & 31 & 29 & 54 & 38 & 9770.00 \\
\hline 8 & WRC26 & 47 & 54 & 50 & 6 & 27 & 48 & 10521.00 \\
\hline 9 & WRC17 & 37 & 36 & 40 & 49 & 20 & 48 & 9567.00 \\
\hline 10 & WRC1 & 43 & 34 & 31 & 54 & 54 & 38 & 8958.00 \\
\hline 11 & WRC21 & 27 & 37 & 40 & 48 & 7 & 38 & 8593.00 \\
\hline 12 & WRC16 & 39 & 19 & 50 & 31 & 54 & 38 & 8395.00 \\
\hline 13 & WRC22 & 27 & 23 & 40 & 44 & 20 & 54 & 8518.00 \\
\hline 14 & WRC9 & 30 & 34 & 23 & 51 & 36 & 38 & 7770.00 \\
\hline 15 & WRC38 & 43 & 27 & 46 & 17 & 20 & 38 & 8431.00 \\
\hline 16 & WRC30 & 44 & 54 & 11 & 14 & 20 & 38 & 7975.00 \\
\hline 17 & WRC6 & 37 & 25 & 54 & 41 & 54 & 3 & 7403.00 \\
\hline 18 & WRC4 & 8 & 54 & 23 & 45 & 54 & 48 & 8076.00 \\
\hline 19 & WRC27 & 37 & 34 & 31 & 28 & 7 & 38 & 7955.00 \\
\hline 20 & WRC39 & 43 & 12 & 46 & 21 & 7 & 54 & 8476.00 \\
\hline 21 & WRC8 & 2 & 34 & 48 & 50 & 54 & 48 & 8165.00 \\
\hline 22 & WRC18 & 43 & 30 & 3 & 31 & 36 & 54 & 7405.00 \\
\hline 23 & WRC23 & 28 & 39 & 31 & 20 & 36 & 38 & 7595.00 \\
\hline 24 & WRC24 & 8 & 54 & 23 & 37 & 20 & 38 & 7362.00 \\
\hline 25 & WRC48 & 50 & 14 & 46 & 2 & 54 & 38 & 7745.00 \\
\hline 26 & WRC20 & 11 & 54 & 31 & 15 & 54 & 48 & 7911.00 \\
\hline 27 & WRC50 & 50 & 2 & 52 & 10 & 7 & 38 & 7574.00 \\
\hline 28 & WRC13 & 37 & 30 & 11 & 26 & 54 & 38 & 6656.00 \\
\hline 29 & WRC40 & 27 & 8 & 48 & 35 & 20 & 38 & 7147.00 \\
\hline 30 & WRC32 & 52 & 22 & 5 & 7 & 36 & 54 & 6940.00 \\
\hline 31 & WRC10 & 1 & 54 & 23 & 33 & 27 & 38 & 6912.00 \\
\hline 32 & WRC25 & 6 & 54 & 9 & 38 & 20 & 38 & 6529.00 \\
\hline 33 & WRC29 & 32 & 21 & 23 & 27 & 36 & 38 & 6570.00 \\
\hline 34 & WRC28 & 27 & 18 & 23 & 40 & 7 & 38 & 6449.00 \\
\hline 35 & WRC37 & 45 & 11 & 3 & 32 & 1 & 54 & 6471.00 \\
\hline 36 & WRC41 & 17 & 35 & 40 & 14 & 20 & 38 & 7138.00 \\
\hline 37 & WRC11 & 11 & 54 & 5 & 54 & 36 & 3 & 5304.00 \\
\hline 38 & WRC47 & 30 & 38 & 23 & 5 & 20 & 38 & 6820.00 \\
\hline 39 & WRC19 & 27 & 4 & 23 & 48 & 54 & 38 & 5940.00 \\
\hline 40 & WRC35 & 27 & 26 & 3 & 25 & 27 & 48 & 5926.00 \\
\hline 41 & WRC34 & 17 & 3 & 40 & 37 & 36 & 38 & 6001.00 \\
\hline 42 & WRC46 & 39 & 10 & 23 & 11 & 36 & 38 & 5933.00 \\
\hline 43 & WRC31 & 13 & 13 & 40 & 25 & 36 & 38 & 6037.00 \\
\hline 44 & WRC42 & 27 & 28 & 9 & 16 & 20 & 38 & 5646.00 \\
\hline 45 & WRC36 & 18 & 9 & 40 & 9 & 54 & 48 & 6174.00 \\
\hline 46 & WRC14 & 4 & 17 & 9 & 54 & 54 & 38 & 4863.00 \\
\hline 47 & WRC33 & 4 & 15 & 23 & 35 & 20 & 38 & 5002.00 \\
\hline 48 & WRC43 & 17 & 6 & 31 & 19 & 27 & 38 & 5218.00 \\
\hline 49 & WRC44 & 6 & 5 & 40 & 25 & 20 & 38 & 5232.00 \\
\hline 50 & WRC49 & 20 & 24 & 9 & 8 & 20 & 38 & 4873.00 \\
\hline 51 & B1 & 14 & 16 & 12 & 18 & 21 & 40 & 4644.00 \\
\hline 52 & WRC45 & 9 & 7 & 40 & 5 & 54 & 38 & 5027.00 \\
\hline 53 & WRC51 & 20 & 20 & 31 & 1 & 7 & 3 & 3977.00 \\
\hline 54 & WRC52 & 13 & 1 & 31 & 5 & 27 & 39 & 4442.00 \\
\hline
\end{tabular}




\section{Analyze the results obtained by the classification}

While analyzing table 11 , we see that 4 WRCs were placed in class A, i.e. closer to Self-Management, and 3 WRCs were placed in class $C$, more distant from self-management. Most of the WRCs were placed in Class B, showing that they have some self-management and others do not.

It is possible to see that the WRC 12 , best placed in the ranking, was placed in class $A$ in three criteria and in class $B$ in the other three. As we go down in the table, the evaluations of class $A$ by criterion decrease and the number of evaluations in class $\mathrm{C}$ increases.

No WRC is placed in the same class in all of the criteria, which shows the complexity and contradictions inherent to the self-management processes. We found evaluations of class $A$ in the last category and evaluations of class $\mathrm{C}$ in the first.

The companies E23 and E29, which have five class B ratings, are the ones that appear to be more regular. However, E48 stands out for the opposite. It has three very good ratings (class $\mathrm{A}$ ) and other three very bad ones (class $\mathrm{C}$ ).

The experts' analysis on the final result produced by the application of the De Borda method confirms that the WRCs perceived by them as closer to self-management are on the top part of the table, and that the experiences that are more distant from self-management are in the bottom part of the table. As for the WRCs that were placed in class B, the experts understand that they have some self-management elements, but they need to advance in other points.

At last, it is noteworthy that in the criterion 6 - self-assessment - some companies well positioned in the ranking were "poorly rated", i.e. they were placed in class C for that criterion. Actually, what we see is that, for this criterion, a few companies were placed in classes $A$ and $B$, and the majority were placed in $\mathrm{C}$.

\section{CONCLUSION}

This work had the purpose of proposing a model for assessing the self-management processes in course in the worker-recovered companies.

The investigation was started by defining criteria to be adopted for that assessment. A bibliographic review on the theme of self-management allowed listing as criteria: (1) the company's tie with the movements and/or principles related for self-management; (2) the opening for incorporating new partner-workers; (3) the differences between the company workers' payments; (4) work organization elements; and (5) the collective participation in the areas of power.
Then we searched the questionnaire used by the WRCs national mapping for questions that were able to produce answers that would allow assessing the companies at the light of the criteria. Different weights were assigned to each question of the questionnaire, which added to each criterion total weight.

The next step was the judgment of the companies' answers to the questions considered, which produced a score for the WRCs by criterion. That score was used to rank and classify the companies in three categories, still by criterion. Finally, the values related to the companies' position in the ranking of each criterion were added, producing a final score for the company, a final ranking, as well as a final classification of the cases researched.

The classification produced by the multi-criteria modeling suggests that, from the 52 WRCs considered in the analysis, 4 were placed in the first category. In other words, their concrete experiences are close to a theoretical ideal of self-management. In the third category are 3 companies, showing a bigger gap between them and the ideal of self-management found in the bibliographic review. The other 43 companies analyzed were placed in the intermediate category, showing the presence of some self-management elements and lacking others.

The multi-criteria approach allowed creating an evaluation of self-management practices in the WRCs studied. The classification originated from that process was submitted to be analyzed by experts, who confirm that the companies that were in the first category are, in fact, the most advanced self-management experiences in the country. That classification may be used to guide future researches in this field, as well as the model may be replicated by these or other companies in Brazil and in the world with the purpose of tracking the trends of self-management in WRCs.

Finally, we remind that this analysis used the database produced by the WRCs national mapping, originated from an essentially quantitative research, and therefore it has limitations regarding its ability to produce analyses about the self-management processes experienced in the companies. Qualitative approach researches, focused on each company particular cases, may reveal other self-management aspects in the companies and thus complement the analysis herein presented.

It is acknowledged that it is a very hard exercise to classify the WRCs as farther from the ideal of self-management or closer to it based on quantitative data. Self-management is a complex social phenomenon. However, it is also pertinent to acknowledge the need for thinking of ways to assess such experiences in a large scale. In this sense, this article exercise has proved to be important. 
Brazilian Journal of Operations \& Production Management Volume 14, Número 1, 2017, pp. 249-264 DOI: 10.14488/BJOPM.2017.v14.n2.a13

\section{REFERENCES}

Anthony, J. (2011), Saving companies worth saving: Spain pioneers a sustainable model of democratic corporate governance. Economic and Industrial Democracy, Vol. 32, No. 4, pp. 697-720.

Araujo, F. (2009) Economia Solidária e Autonomia: uma análise das relações sociais de produção em dois empreendimentos econômicos solidários de beneficiamento de pescado. Rio de Janeiro: UFRJ/COPPE.

Benini. E. (2012) Sistema Orgânico do Trabalho: Arquitetura Crítica e Possibilidades - 1ạ ed. - São Paulo: Ícone.

CEPAL (1997) Anuário Estatístico da CEPAL, 1997. Available at: http://websie.eclac.cl/infest/ajax/cepalstat. asp?carpeta=estadisticas (Accessed February 10, 2010.

Cornforth Chris (2004) The Governance of Cooperatives and Mutual Associations: A Paradox Perspective, Annals of Public and Cooperative Economics, Vol. 75, No. 1, pp. 11-32.

Costa, H. G.; Mansur, A. F. U.; Freitas, A. L. P.; Carvalho, R. A. (2007) ELECTRE TRI aplicado a avaliação da satisfação de consumidores. Produção, Vol. 17, No. 2, pp. 230-245.

Costa, H. G.; Soares, A. C.; De Oliveira, P. F (2004) Avaliação de transportadoras de materiais perigosos utilizando o método ELECTRE TRI. Gestão \& Produção, Vol. 11, No. 2, pp. 221-229.

Dejours, C. (2008) Avaliação do trabalho submetida à prova do real, Cadernos de TTO, No. 2, São Paulo: Blucher.

Deutsch, S. (2005) A researcher's guide to worker participation, labour and economic and industrial democracy. Economicand Industrial Democracy, Vol. 26, No. 4, pp. 645-665.

Freitas, A. L. P.; Costa, H. G. (1998) Avaliação e classificação da qualidade de serviços utilizando uma abordagem multicritério. Gestão \& Produção, Vol. 5, No. 3, pp. 272-283.

Guillerm, A.; Bourdet, Y. (1976), Autogestão: uma mudança radical. 1 ed. Rio de Janeiro: Zahar.

Henriques, F. C; Sigolo, V., Rufino, S. et al. (2013), Empresas Recuperadas por Trabalhadores no Brasil. Rio de Janeiro: Multifoco.

Karyotis, T (2014). Report from the "Workers' Economy" international meeting, January 31 and February 1, occupied factory of Fralib, Marseille. Available at: http://www.autonomias.net/2014/02/report-from-workers-economy.html (Accessed February 3, 2015).
Lima, J. C. (2007), Workers' Cooperatives in Brazil: Autonomy vs Precariousness. Economic and Industrial Democracy, Vol. 28, pp. 589-621.

Logue, J.; Yates, J. S. (2006), Cooperatives, Worker-Owned Enterprises, Productivity and the International Labor Organization. Economic and Industrial Democracy, Vol. 27, No. 4, pp. 686-690.

Mansur, A. F. U.; Costa, H. G. (2000), Aplicação da metodologia ELEQUAL para avaliação da qualidade em serviços: um estudo de caso. Anais do Encontro Nacional de Engenharia de Produção - ENEGEP. ABEPRO.

Mygind N (1992) The choice of ownership structure. Economic and Industrial Democracy, Vol. 13, pp. 359-399.

Nascimento, C. (no date) Autogestão e economia solidária. Available at: http://www.tau.org.ar/upload/89f0c2b656ca02f f45ef61a4f2e5bf24/nascimento_autogest.pdf (Acessado em 15 de novembro de 2014)

Ness, I.; Azzelini, D. (2011), Ours to Master and to Own: Workers' Control from the Commune to the Present. Chicago, Illinois: Haymarket Books.

Ruggeri, A. (2009). Las empresas recuperadas: autogestiónobrera em Argentina y América Latina. Buenos Aires: Editorial de La Facultad de Filosofia y Letras Universidad de Buenos Aires.

Ruggeri, A. (2014), Informe del IV relevamiento de Empresas Recuperadas em la Argentina: las empresas recuperadas em el período 2010-2013. 1. ed., Ciudad Autónoma de Buenos Aires: Cooperativa Chilavert Artes Gráficas.

Schwartz, Y. (1996) Trabalho e valor. Tempo Social, Revista Sociologia da USP, Vol. 8, No. 2, pp. 147-158.

SERASA (2010). Available at http://www.serasa.com.br/ release/indicadores/falencias_concordatas.htm (Accessed February 20, 2010).

Singer, P (2001), Economia Solidária versus economia capitalista. Sociedade e Estado, Vol. 16, No. 1-2, Brasília.

Viggiani, F. A (1997), Democratic Hierarchies in the Workplace: Structural Dilemmas and Organizational Action. Economic and Industrial Democracy, Vol. 18, pp. 231-60.

Westenholz, A. (1999) From a Logic Perspective to a Paradox Perspective in the Analysis of an Employee-Owned Company. Economic and Industrial Democracy, Vol. 20, pp. 503-34. 